\title{
¿s Research Square \\ Comparison of emission profile of black carbon and carbon monoxide over Eastern India: source apportionment and health risk impact
}

\author{
Balram Ambade \\ National Institute of Technology Jamshedpur \\ Tapan Kumar Sankar \\ National Institute of Technology Jamshedpur \\ Lokesh K. Sahu \\ PRL: Physical Research Laboratory \\ Sneha Gautam ( $\sim$ gautamsneha@gmail.com ) \\ Xi'an Jiaotong University \\ Alok Sagar Gautam \\ HNBGU: Hemwati Nandan Bahuguna Garhwal University
}

\section{Research Article}

Keywords: Aethalometer, Backward Trajectory, Black carbon, Emission sources, Health Risk Assessment

Posted Date: April 20th, 2021

DOI: https://doi.org/10.21203/rs.3.rs-388630/v1

License: (c) (i) This work is licensed under a Creative Commons Attribution 4.0 International License. Read Full License 


\section{Abstract}

In the present study, black carbon (BC) mass concentration and carbon monoxide (CO) combination ratio were calculated simultaneously at two different cities (i.e.,Jamshedpur (JSR) and Kharagpur (KGP)) located in the eastern state of India. The analysis of GIOVANI NASA data indicates the highest concentrations of BC and CO in the Indo-Gangetic Plain (IGP) as well as the eastern part of India. The BC-CO relationship exhibited an excellent positive correlation $\left(r^{2}=0.65\right)$, while BC$\mathrm{PM}_{2.5}$ showed a strong positive correlation $\left(\mathrm{r}^{2}>0.96\right)$. On the other hand, the backward air trajectory showed pollutant transport mainly from India's northern part with some contributions from other countries likePakistan, Nepal, Bhutan etc. BC concentration overall health risk assessment was demonstrated as 6.27, 12.43, 11.22 and 25.60 in JSR and 2.02, 4.02, 3.63 and 8.28 in KGP, passive cigarettes comparable concerning the risk of lung cancer, low birth weight, cardiovascular mortality, and percentage lung function decrement of school-aged children.

\section{Introduction}

Particulate matters, black carbon (BC), and various gaseous air pollutants favorably impact the environment's atmosphere and climate change processes. The carbonaceous aerosols, composed of BC and organic carbon (OC), are fundamental aerosol particles and essential components (Prasad et al. 2018). Due to its small dimesion, large specific surface area, and BC's irregular morphology, it makes the study unique. BC can absorb carcinogenic /mutagenic pollutants such as volatile organic compounds (VOCs) and polycyclic aromatic hydrocarbons (PAHs) through the bronchial (Janseen et al. 2012; Dachs and Eisereich 2000). Increasing aerosol emission directly affects the upper and middle troposphere. BC impacts the Earth's climate either incidentally through its behavior as cloud condensation nuclei or directly through solar radiation absorption (Bond et al. 2013). Latest studies have shown that after $\mathrm{CO}_{2}, \mathrm{BC}$ may be the next-highest contributor to the Greenhouse effect (GHE) (Liu et al. 2018; Babu and Moorthy 2002). It also contributes an essential role in comprehensive BC dispersal and radiation budget (Huang et al. 2013; He et al. 2016). It is well established that small carbonaceous particles cause severe health effects because they can easily enter the human respiratory system (Oberdorster et al. 2002). According to epidemiological studies, the respiratory health effects in children and cardiovascular diseases are significantly associated with BC (Peters et al. 2000). In the industrial area, in addition to fossil fuel-based emissions, coal and wood burning is a chief cause of air pollutants during the wintertime (Lanz et al. 2008; Szidat et al. 2006). BC emission has been continuously increasing because of urbanization, energy demands, economic growth, industrialization, uncontrolled agricultural waste burning, peat fire and wood fires in the east and south Asia regions (Chen et al. 2001). According to BC's emission estimates, about $40 \%$ of the contribution comes from open biomass burning, $40 \%$ from fossil fuel burning, and 20\% from bio-fuel burning. Bio-fuel burning and agricultural residue fires have been recognized as the largest sources of BC over the Indo-Genetic Basin (IGB) areas (Venkataraman et al. 2001).

Carbon monoxide (CO) is an air pollutant and mainly emitted into the atmosphere from the incomplete burning of fossiland bio-fuels (Sahu et al. 2020). In polluted regions, CO is emitted from domestic wood burning, cigarette smoke, chimneys, and its concentrations from 0.1 ppm in clean air to 5000 ppm in pollutant air (Fawcett et al. 1992; Hoffmann et al. 2001). However, in comparison to other pollutants, $C O$ has longer lifetimes of 1-2 months in the atmosphere (Akimoto 2003). The prevention and emission control measure of $\mathrm{CO}$ is an essential aspect of public health. $\mathrm{CO}$ is an indirect greenhouse gas through the production of carbon dioxide $\left(\mathrm{CO}_{2}\right)$, ozone $\left(\mathrm{O}_{3}\right)$ (Girach et al. 2014). Typically, $\mathrm{CO}$ and $\mathrm{BC}$ are co-emitted from incomplete combustion of carbon-based fuels (Wang et al. 2020). In addition to various anthropogenic or fuel-based emissions, forest/wildfire activities significantly impact the variability of $\mathrm{BC}, \mathrm{CO}$, and $\mathrm{O}_{3}$ in the Northern Hemisphere (Bond et al. 2011; Vander et al. 2006). Overall, biomass burning is a significant source of climate-altering species and atmospheric pollutants (Simmonds et al. 2005). Incomprehensible deaths illnesses are linked to malfunctioning chimneys resulting in $\mathrm{CO}$ poisoning. $\mathrm{CO}$ makes it a widespread source of poisoning and unnatural death in the USA. Despite that CO is not on the list of chemical weapons (Elsayed et al. 2006). 
We have conducted the measurements of ambient air BC, CO, and $\mathrm{PM}_{2.5}$ concentrations from October 2019 to January 2020 in two different eastern Indian cities to assess their source apportionment and health risk impact. The observations of $\mathrm{BC}$ and $\mathrm{CO}$ concentrations at JSR and KGP cities will help understand the dominant local sources of carbonaceous aerosols, health risks, and the role of atmospheric conditions over East India.

\section{Geographical Location Of Sampling Sites}

The locations of KGP and JSR in India's map and localities images in these two cities are displayed in Fig-1. PM $2.5, \mathrm{BC}^{2}$ and $\mathrm{CO}$ concentrations were collected from two different cities in India eastern part. The KGP city $\left(22^{\circ} 33^{\prime} \mathrm{N}, 87^{\circ} 32^{\prime} \mathrm{E}\right)$ is situated in the state (province) of West Bengal and JSR city $\left(22^{\circ} 80^{\prime} \mathrm{N}, 86^{\circ} 20^{\prime} \mathrm{E}\right)$ is located in the state of Jharkhand. KGP is the fifth most populated and fourth-largest city in the area wise after Kolkata, Durgapur, and Asansol cities of West Bengal. The total area of KGP is about $127 \mathrm{~km}^{2}$ in the southern part of West Medinipur district and this town is formed with the alluvial tract and Dalma Pahar of Medinipur. It has a tropical savanna climate. The average temperatures are around $22^{\circ} \mathrm{C}$ and $30^{\circ} \mathrm{C}$ in winter and summer, respectively. The mean annual precipitation is around $1401 \mathrm{~mm}$. According to the 2011 census, KGP had a population of 293,719 . KGP city is surrounded by a railway network, National Highways (NH) network, Vidhyasagar industrial park, Railway Workshop, etc. In Vidhyasagar industrial park, so many small and large industries are situated.

JSR city is located over the Chhota Nagpur Plateau (CNP) region in the southern part of Jharkhand state, India. JSR is a densely populated city, and according to the 2011 census, the residents of the city is about 1.3 million. The world-known largest industries, namely the Tata Iron and Steel Company (TISCO),TATA motors and are located in JSR city. The Adityapur Industrial Development Authority (AIDA) region is very close to JSR city, where more than 1001 companies (minor, average, and big enterprises) are located. Air pollutants major sources in these two cities are chiefly emissions from industrial activities, transportation discharges, road construction, and town construction.

\section{Measurements And Methodologies}

\subsection{Measurement of $\mathrm{BC}$ mass concentration}

Continuous real-time measurement of $\mathrm{BC}$ mass concentrations was performed with the Aethalometer (Model AE-33, Magee Scientific Company, USA) instrument. BC aerosol's mass concentration was deduced from the analysis of seven different wavelengths i.e., $370 \mathrm{~nm}, 470 \mathrm{~nm}, 525 \mathrm{~nm}, 590 \mathrm{~nm}, 660 \mathrm{~nm}, 880 \mathrm{~nm}$, and $940 \mathrm{~nm}$. Out of all wavelengths, 880 $\mathrm{nm}$, a light ray from a high energy light-emitting-diode light was transferred through the sample collected on the filter strip. This is a simple and efficient technique to measure BC's ambient air mass concentration associated to the supplementary design alike the coefficient of haze tape sample, particle soot absorption photometer (PSAP), melting oxidation/reflectance, etc. (Allen et al. 1999). This technique is based on attenuation of light due to the mass load of BC particles accumulate on a filter. The air inlet is equipped on the Department of Chemistry rooftop, NIT JSR city, and Railway quarter building at KGP city. Atmospheric air is drawn through the inlet line at the flow rate ( 5 LPM), which hit on a quartz filter. BC mass concentrations were recorded on the duratation of every 5 minutes. Bestowing to the guideline and literature reviews, $880 \mathrm{~nm}$ is the regular wavelength to measure $\mathrm{BC}$ mass concentration. $\mathrm{BC}$ shows principal absorber of energy at this wavelength and other aerosol components have negligible absorption (Weingartner et al. 2003).

\subsection{Measurement of $\mathrm{PM}_{2.5}$ and $\mathrm{CO}$ concentrations}

$\mathrm{PM}_{2.5}$ was also examined along with $\mathrm{BC}$ and $\mathrm{CO}$ concentrations in both the cities. The $\mathrm{PM}_{2.5}$ sample was collected using a mini volume sampler (Envirotech Model APM 550) from October 2019 to January 2020. The mini sized sampler was operated at a constant flow rate of $16.5 \mathrm{~L} / \mathrm{m}^{3}$. PTFE filter (47 mm, Merck, catalog no- PM2547050) was used to gather particulate matter (PM). At first, the filter paper was weighed before and after the sampling and kept in a desiccator. 
Weight balance with a single pan-top loading digital weight balance (VWR, Model no: VWR1611-2263: with measuring apartment $\mathrm{L} \times \mathrm{W} \times \mathrm{H}: 162 \times 171 \times 225 \mathrm{~mm}$ ). Background infection was investigate using operational blanks (unexposed filters), which were processed concurrently with field samples. Moreover, the sample filter was stored in a desiccator box. These samples were held at $4^{\circ} \mathrm{C}$ for storage and then weights of filter paper before sampling and after sampling was measured.

Similarly, $\mathrm{CO}$ concentration was also measured in both cities. The concentration (mixing ratio) of $\mathrm{CO}$ was carried out using a extensive gas filter non-dispersive IR (infrared) gas analyzer (Thermo Scientific. Model 48C, USA). A Nafion has been used to reduce water vapor interferences present in air samples (ambient air). The time resolution and detection limits were $1 \mathrm{~min}$ and $30 \mathrm{ppbv}$ for $2 \mathrm{~min}$ average, respectively. The equipment baseline signal was determined in the first $15 \mathrm{~min}$ of each hour by supplying zero-air. Before the ambient air measurements, the span calibration was performed carefully.

\subsection{Health risk assessment}

In the current study, health risk estimates of BC pollution were carried out to determine the disease's overall concern due to environmental tobacco smoke (ETS) exposure. Our evaluations are based on the assumptions reported in van der Zee et al. 2016, i.e., 14 daily cigarette utilization as per WHO assessment for smokers in the US as well as North-West Europe. The health risks of BC pollution are approximately equal to passive smoking (Niranjan et al. 2017; Vander et al. 2006). There are mainly three-zone reasons to co-relate the health risk between passive smoking and BC. These zones (a) both hazards have equal exposure through inhalation (b) both hazards have some type of health effects and (c) exposure to both ETS and atmospheric BC pollution is commonly spontaneous (Vander et al. 2006). In the present study, we have assessed the health risk of atmospheric BC pollution to local inhabitants of two different cities in the eastern part of India. In JSR and KGP cities, analogous extents of passive cigarette smoking for potential receptors are comprehended. According to recent scientific studies, people living in different parts of the world are facing serious health threats like non-cancer (respiration related problems, cardiovascular problems, etc.) and cancer (especially lung cancer) diseases due to exposure to BC (Magalhaes et al. 2018; Kelly et al. 2015). the small particulate size of BC is direct air inhalations from local or regional sources' proximity. Van der et al. (2016) has developed a module by which we can easily calculate the health risk evaluation based on ETS. The ETS values are helpful to estimate the risks of BC exposure related to the following four different health issues. i.e., (i) lung cancer (LC), (ii) low birth weight (LBW), (iii) cardiovascular mortality (CVM), and (iv) percentage lung function decrement of school-aged children (PLFDSC). The links between all the four health issues with both ETS exposure and BC pollution are well established (Kelly et al. 2015; Oberg et al. 2010; WHO 2014). The estimation of health risk primarily depends on relative risks (RRs) relative to a different health issue for air pollutants like ETS exposure and $\mathrm{BC}$ pollution; where RR refers to the possibility of growing an illness induced by the exposure to air pollutants (Rothman et al. 2008; WHO 2003). The value of $R_{B C}$ and $R R_{E T S}$ are derived from detailed, systematic reviews and can be summarized to implement the relevant, yet immature, health risk estimates. The specified change in BC concentration and health risk issue was characterized by a meta-analysis of recorded concentration-response functions (CRFs). For a particular health issue (i.e., R), the BC concentration increases by $1 \mu \mathrm{g} \mathrm{m}^{-3}$, equivalent to the number of passively smoked cigarettes (PSC) (Vander et al. 2006). Therefore, $\mathrm{R}$ is written as

$\mathrm{R}=\left[\ln \left(\mathrm{RR}_{\mathrm{BC}}\right) / \Delta\right.$ Concentration $] /\left[\ln \left(\mathrm{RR}_{\mathrm{ETS}}\right) /\right.$ assumed number of PSC $]$

Where,

$\left[\ln \left(\mathrm{RR}_{\mathrm{BC}}\right) / \Delta\right.$ Concentration $]=$ the resultant risks for change in $\Delta$ Concentration (i.e., $1 \mu \mathrm{g} \mathrm{m}^{-3}$ ) of BC.

$\left[\ln \left(\mathrm{RR}_{\mathrm{ETS}}\right) /\right.$ assumed number of PSC] = the resultant risks of ETS exposure for the assumed number of PSC per day.

$\mathrm{RR}_{\mathrm{BC}}=\mathrm{RR}$ of $\mathrm{BC}$ concerning particular health issues. 
$\mathrm{RR}_{\mathrm{ETS}}=\mathrm{RR}$ of ETS concerning particular health issues.

The values of $\mathrm{RR}_{\mathrm{ETS}}$ and $\mathrm{RR}_{\mathrm{BC}}$ were taken from van der et al. (2006) and Pani et al. (2020). The assumed number of PSC varies depending on the case. In the case of PLFDSC, the assumed number of PSC per day is 9 . For the child of the nonsmoking mother, the assumed number of PSC per day is 7 for CVM and LC as well as for adults about the risk of LBW (Vander et al. 2006). The following equations estimate the equivalent numbers of PSC per day (i.e., NPSC: passive cigarette-equivalence).

$\mathrm{NPSC}=\mathrm{R} \times \triangle \mathrm{BC}$

and

$\Delta \mathrm{BC}=\left[\left(\mathrm{BC}_{\mathrm{obs}}\right)-\left(\mathrm{BC}_{\mathrm{bac}}\right)\right]$

Where,

$\mathrm{BC}_{\mathrm{obs}}=$ Observed Black Carbon Aerosol and $\mathrm{BC}_{\mathrm{bac}}=$ Background Black Carbon Aerosol.

\subsection{Source appropriation}

Significant sources of BC aerosols are incomplete combustions of biofuel burning and fossil fuel in the atmosphere (Petzold et al. 2013). The aethalometer model was used to determine BC's source appropriation (Fuller et al. 2014; Sciare et al. 2011). Although this model identifies broad source categories like wood-burning, traffic emission, fossil fuel, etc. but requires seven different wavelength light absorption data sets (Zotter et al. 2017). This model was the latest and easiest among other methods or models like principal component analysis (PCA) (Thepnuan et al. 2019), Positive matrix factorization (PMF) (Florou et al. 2017), the radiocarbon method (Zhang et al. 2015), the macro-tracer method (Larsen et al. 2012), chemical mass balance (CMB) (Favez et al. 2010), and other specialized models (Belis et al. 2013). To characterize different local sources of BC at JSR and KGP cities, we have calculated the percentage difference of BC measured at two different wavelengths of $370 \mathrm{~mm}$ and $880 \mathrm{~mm}$, i.e., $\mathrm{BC}_{370} \mathrm{BC}_{880}$, respectively. The percentage difference of $\mathrm{BC}$ can be written as

$\%$ difference of $\mathrm{BC}=\left(\mathrm{BC}_{370}-\mathrm{BC}_{880}\right) / \mathrm{BC}_{880}$

From Eq. (5), two cases may arise, Case-I for fossil fuel and case-Il for wood burning.

Case-l: - The negative fractional BC values suggest major contributions from the combustion of diesel and petrol (Herich et al. 2011).

Case-II: - The positive fractional BC values suggest major contributions from the forest fire, domestic use product like coal, dry leaf, etc. (Wang et al. 2011). We also describe the source appropriation of $B C, C O$, and $\mathrm{PM}_{2.5}$ mass concentrations with the help of air backward trajectory.

\section{Results And Discussion}

\subsection{Variation of $\mathrm{BC}, \mathrm{CO}$, and $\mathrm{PM}_{2.5}$}

BC's mass concentrations were measured from October 2019 to January 2020 at two different places in the eastern part of India. The average BC mass concentrations of $10.06 \pm 1.59 \mu \mathrm{gm}^{-3}$ at JSR and $5.49 \pm 1.15$ at KGP were measured during the study period. The variations in monthly mean BC mass concentration along with standard deviation from October 2019 to January 2020 are shown in Fig. 3.a. In JSR, the monthly average BC mass concentrations were $8.99 \pm 1.77,9.73 \pm$ 
$1.84,10.81 \pm 1.82$ and $10.53 \pm 0.97 \mu \mathrm{gm}^{-3}$ in October, November, December of 2019 and January 2020, respectively. In KGP, the monthly average BC mass concentrations were $5.05 \pm 0.60,4.95 \pm 0.47,6.67 \pm 1.74$ and $5.62 \pm 0.89{\mu g m^{-3}}$ in October, November, December of 2019 and January 2020, respectively. From sample-to-sample, BC concentrations varied

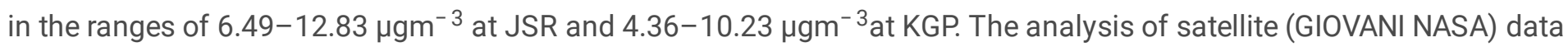
reveals much higher loadings of BC aerosols over the Indo-Gangetic Plain (IGP) than other regions of India. It was also demonstrated that the $\mathrm{BC}$ mass concentrations were reported to be approximately $3.5 \mathrm{\mu gm}^{-3}$ to $5 \mu \mathrm{gm}^{-3}$ during study period (Fig- 2.a).

Simultaneously, $\mathrm{CO}$ and $\mathrm{PM}_{2.5}$ concentrations were also measured from October 2019 to January 2020 in JSR and KGP cities. The average CO concentrations of $913.63 \pm 217.85$ ppbv at JSR and $507.31 \pm 125.06$ ppbv at KGP were measured during the study period. The average $\mathrm{PM}_{2.5}$ concentrations were $176.34 \pm 24.40 \mu \mathrm{gm}^{-3}$ at JSR and $107.28 \pm 13.60 \mu \mathrm{gm}^{-3}$ at KGP. The monthly mean concentrations of $\mathrm{CO}$ and $\mathrm{PM}_{2.5}$ along with standard deviations are shown in Fig. 3.b and Fig. 3.c, respectively. In JSR, the average CO concentrations of $953.89 \pm 278.12,870.47 \pm 172.12,958.53 \pm 196.24$ and $871.31 \pm 236.41$ ppbv were measured in October, November, December of 2019 and January 2020, respectively. The average $\mathrm{PM}_{2.5}$ concentrations were $162.78 \pm 32.43,179.98 \pm 25.16,183.93 \pm 21.63$ and $177.55 \pm 15.82 \mu \mathrm{gm}^{-3}$ in October, November, December of 2019 and January 2020, respectively. Overall, CO concentrations varied in the range of 416$1402.32 \mathrm{ppbv}$ and $\mathrm{PM}_{2.5}$ in the range of $105.98-210{\mu \mathrm{gm}^{-3}}^{-3}$ during the study period. In KGP, the average CO concentrations were $542.75 \pm 96.30,419 \pm 97.63,538.54 \pm 114.01$ and $535 \pm 160.37$ ppbv in October, November, December of 2019 and January 2020, respectively. While $\mathrm{PM}_{2.5}$ concentrations were $103.54 \pm 9.04,101.74 \pm 7.76,118.73 \pm 20.42$ and $106.265 \pm 9.19 \mu^{-3} \mathrm{gm}^{-3}$ in October, November, December of 2019 and January 2020, respectively. CO concentrations varied from 257.8 to $840.6 \mathrm{ppbv}$ and $\mathrm{PM}_{2.5}$ concentrations varied from 87.13 to $163.12 \mu \mathrm{gm}^{-3}$ during the study period. The GIOVANI NASA data analysis indicates significantly higher concentrations of CO over the IGP compared to other regions of India. The GIOVANI CO concentrations were 450-773 ppbv in India's eastern part during the study period (Fig- 2.b).

The concentrations of $\mathrm{BC}, \mathrm{CO}$, and $\mathrm{PM}_{2.5}$ in JSR were higher than those in KGP. More and more industries are present, dense traffic connectivity, and more vehicles than KGP, where fewer sectors, moderate traffic connectivity, and fewer cars are current.

\subsection{Health risk assessment}

We have attempted to evaluate the health risk assessments of $\mathrm{BC}$ in both cities. The health risk assessment summary indicated an equal number of PSC for a particular investigation period, as shown in Table-3. We considered that the day to daily exposure level of BC for the people living in JSR city and KGP city was equivalent to day to day mean BC (balance load concerning the background $\mathrm{BC}$ ) level. According to previous studies, the estimates were presented for an increment of $1 \mathrm{\mu gm}^{-3}$ in BC concentration. As per Rupakheti et al. (2017), the background $B C\left(B_{\text {bac }}\right)$ concentration level was determined as the 1.25th percentile of the observed $\mathrm{BC}\left(\mathrm{BC}_{\mathrm{obs}}\right)$ concentrations, which are $6.571 \mu \mathrm{gm}^{-3}$ for JSR city and $4.362 \mu \mathrm{gm}^{-3}$ for KGP city. These increments are generally used to explicit relative risks of BC mass concentration of JSR city. The health risk assessment of BC aerosols concentration was demonstrated as 6.27, 12.43, 11.22 and 25.60 passive cigarettes-comparable concerning the risk of CVM, LC, LBW, and PLEDSC, respectively. And in KGP city, the health risk assessment of $\mathrm{BC}$ aerosols concentration was notice as 2.02, 4.02, 3.63 and 8.28 passive cigarettes comparable concerning the risk of CVM, LC, LBW, and PLEDSC, respectively. It was noticed that the health risk issue is higher in JSR city as compared to KGP city during the study period. This is because of increased air pollutants like $B C, C O$, and $\mathrm{PM}_{2.5}$ in JSR city compared to KGP city.

$\mathrm{CO}$ is a very serious air pollutant in the atmosphere. $\mathrm{CO}$ affects human health very drastically. It hard bond with hemoglobin $(\mathrm{Hb})$ molecule and forming carboxyhemoglobin $(\mathrm{COHb})$. As a result, the oxygen-carrying capacity of the blood is reduced. Hb's affınity for $\mathrm{CO}$ is higher than an affinity for oxygen, i.e., 210 to 300 times higher than its affinity for oxygen. 


\section{3 source appropriation of $\mathrm{BC}$ and $\mathrm{CO}$}

The aethalometer model was used to determine the major sources of $\mathrm{BC}$ in ambient air. While the projected model was characterized by a few selective source-categories like traffic emission and wood-burning. According to SAFAR 2010, the primary sources of $\mathrm{BC}$ were coal burning, and it is the highest source of energy that supplies $76 \%$ of our requirement in India. The origins of $\mathrm{BC}$ aerosols and $\mathrm{CO}$ may have the same, but their source apportionment techniques are different. According to a previous study, it was observed that the analysis of BC measured at $370 \mathrm{~nm}$ (UV) wavelengths and $880 \mathrm{~nm}$ (near-IR) wavelengths were made, which is favorable for the source identification of BC mass concentration (Sivastava et al. 2012). There are two types of processes for sources of BC mass concentration. One is anthropogenic activities like biomass burning for agriculture, coal burning, burning of fossil fuel, vehicular movements, and another natural process like volcanic eruptions, forest fires, etc. Still, fossil fuel and wood-burning are the major sources. The source differentiates between wood-burning and fossil fuel in different cities were different, as shown in Fig. 6. In JSR city, the fossil fuel contribution was approx. $60 \%$ and wood-burning contribution approx. $40 \%$ toward the source appropriation of BC mass concentration. In KGP city, the fossil fuel contribution was approx. $57.57 \%$ and wood-burning contribution approx. $42.42 \%$ toward the source appropriation of BC mass concentration. Fossil fuel contribution was higher in JSR city as compared to KGP city. It indicates that the traffic load was increased in JSR city than the KGP city of East India.

\subsection{Backward trajectories analysis}

The back trajectories were calculated for both the cities. Backward trajectory analysis helps to understand the sources and transport pathways of air pollutants. It also determines the airflow direction to describe the possible source regions before they reach a specific target. The trajectories were prepared with the help of Igor software. The trajectories data were taken from the Climate Forecast System, and Meteorological Data Explorer developed by the Centre for Global Environmental Research (CGER), Japan and a global environmental dataset online program National Centers for Environmental Prediction (NCEP). Backward trajectories plots are shown in Fig. 5. The back air trajectory analysis indicates that air masses' transport originates from different places from different heights. It can be noticed that air-borne particulate (maybe air pollutants) is transported from the northern part of India. In the JSR region, air masses originated over the north of Jammu and Kashmir, Delhi, Haryana, Punjab, and Uttar Pradesh before entering the eastern state Bihar and some part Jharkhand. Some trajectories also suggest the transport from the north-east states of India. Transport of air masses originated over neighboring countries like Pakistan, Nepal and Bhutan can also be noticed. In the KGP region, maximum air particulate matter was coming from the northern state, i.e., from Delhi, Haryana, Punjab, Uttarakhand and Uttar Pradesh eastern state Bihar, Jharkhand and some part of West Bengal. It was also seen that air particulate matter again came from the north-east state, i.e., from Arunachal Pradesh, Assam and other states. Air particulate matter was also coming from some other countries Bangladesh, Nepal, and Bhutan. The backward air trajectories were shown in Fig. 6.

\subsection{Correlation between $\mathrm{BC}$ and $\mathrm{CO}$}

BC and $\mathrm{CO}$ are emitted from incomplete combustion of carbon-based fuels (Wang et al. 2015). The concentrations of both $\mathrm{BC}$ and $\mathrm{CO}$ in JSR city were higher than those in KGP city. As shown in the scatter plot (Fig- 7.b), the concentrations of BC and $\mathrm{CO}$ show an excellent positive correlation $\left(r^{2}=0.653\right)$ with an average slope $(\Delta \mathrm{BC} / \Delta \mathrm{CO})$ of $6.125 \mathrm{~g} \mathrm{BC} / \mathrm{g} \mathrm{CO}$. The BC$\mathrm{CO}$ correlation parameters determined for different sites are presented in Table 4. The previous studies reporting good correlations between $\mathrm{BC}$ mass concentration and $\mathrm{CO}$ concentration are mainly due to proximate of familiar sources such as traffic emission. Emissions from petrol-fueled vehicles are known to be fewer sources of BC and CO compared to dieselfueled cars. An earlier study on automobile exhausts has suggested that light-duty petrol engines emit lesser amounts of $\mathrm{BC}$ and $\mathrm{CO}$ than heavy-duty vehicles such as diesel trucks (Chen et al. 2001). Far away from the sources, the measurements over the Northern Indian Ocean (Arabian Sea) also suggested a strong positive correlation $\left(r^{2}=0.71\right)$ between BC and CO concentrations with a slope of $27.103 \mathrm{~g} \mathrm{BC} / \mathrm{g}$ CO [49] (Bracero et al., 2002). According to Chen et al. (2001), BC mass concentration and CO concentration are strongly correlated along with an annual average slope of 
$3.48103 \mathrm{~g} \mathrm{BC} / \mathrm{g}$ CO [50]. As shown in Fig. 7.a., we observed a strong positive correlation $\left(r^{2}=0.97\right)$ between $\mathrm{BC}$ and $\mathrm{PM}_{2.5}$ mass concentrations, suggesting their commons emission sources at both the sites. Figure 4. indicated the variation of $B C$ mass concentration and $\mathrm{CO}$ concentration at two different East India cities. As the winter season start, BC mass concentration was starting to increase in both the cities. This is maybe the reason for crop residue burning in the nearest village area of these two cities.

Table 1

Meteorological parameter data at two different cities of East India. i.e., Jamshedpur (JSR) city and Kharagpur (KGP) city during sampling period.

\begin{tabular}{|c|c|c|c|c|c|c|}
\hline & \multicolumn{3}{|l|}{ JSR city } & \multicolumn{3}{|l|}{ KGP city } \\
\hline & Temp. & Hum. & W.S & Temp. & Hum. & W.S \\
\hline & Mean \pm SD & Mean \pm SD & Mean \pm SD & Mean \pm SD & Mean \pm SD & Mean \pm SD \\
\hline Oct-19 & $26.81 \pm 1.99$ & $74.93 \pm 7.80$ & $7.06 \pm 4.46$ & $27.68 \pm 0.84$ & $78.11 \pm 4.70$ & $5.93 \pm 1.66$ \\
\hline Nov-19 & $23.47 \pm 1.50$ & $69.13 \pm 4.46$ & $4.2 \pm 2.54$ & $24.13 \pm 1.48$ & $73.56 \pm 5.54$ & $4.69 \pm 1.50$ \\
\hline Dec-19 & $19.51 \pm 2.11$ & $68.35 \pm 7.30$ & $5.81 \pm 6.50$ & $21.47 \pm 1.58$ & $69.31 \pm 6.58$ & $7.14 \pm 4.37$ \\
\hline Jan-20 & $19.30 \pm 1.93$ & $61.00 \pm 5.15$ & $2.53 \pm 0.76$ & $20.25 \pm 2.50$ & $64.84 \pm 6.49$ & $4.25 \pm 4.12$ \\
\hline
\end{tabular}

Table 2

Monthly mean of $\mathrm{PM}_{2.5}$ concentrations, mass concentrations of $\mathrm{BC}$ and $\mathrm{CO}$ concentration at two different cities of East India.

\begin{tabular}{|c|c|c|c|c|c|c|c|c|c|c|c|c|}
\hline & \multicolumn{6}{|c|}{ JSR city } & \multicolumn{6}{|c|}{ KGP city } \\
\hline & \multicolumn{2}{|l|}{$\mathrm{PM}_{2.5}$} & \multicolumn{2}{|l|}{$\mathrm{PM}_{2.5}$} & \multicolumn{2}{|l|}{$\mathrm{PM}_{2.5}$} & \multicolumn{2}{|l|}{$\mathrm{PM}_{2.5}$} & \multicolumn{2}{|l|}{ BC } & \multicolumn{2}{|l|}{$\mathrm{CO}$} \\
\hline & Mean & SD & Mean & SD & Mean & SD & Mean & SD & Mean & SD & Mean & SD \\
\hline $\begin{array}{l}\text { Oct- } \\
19\end{array}$ & 162.78 & 32.43 & 8.99 & 1.77 & 953.89 & 278.12 & 103.54 & 9.04 & 5.05 & 0.60 & 542.75 & 96.30 \\
\hline $\begin{array}{l}\text { Nov- } \\
19\end{array}$ & 179.98 & 25.16 & 9.73 & 1.84 & 870.47 & 172.12 & 101.74 & 7.76 & 4.95 & 0.47 & 419.51 & 97.63 \\
\hline $\begin{array}{l}\text { Dec- } \\
19\end{array}$ & 183.93 & 21.63 & 10.81 & 1.27 & 958.53 & 196.24 & 118.73 & 20.42 & 6.67 & 1.74 & 538.54 & 114.01 \\
\hline $\begin{array}{l}\text { Jan- } \\
20\end{array}$ & 177.55 & 15.82 & 10.53 & 0.97 & 871.31 & 236.41 & 106.26 & 9.19 & 5.62 & 0.89 & 535 & 160.37 \\
\hline
\end{tabular}

Where, $\mathrm{PM}_{2.5}$ concentrations in $\mu \mathrm{gm}^{-3}$; $\mathrm{BC}$ mass concentration in $\mu \mathrm{gm}^{-3}$; and $\mathrm{CO}$ concentration in pbbv

Table-3: - The health risk estimates of BC communicated into equivalent numbers of PSC per day with respect to four various health issues at two different cities. 


\begin{tabular}{|lll|}
\hline Parameters & JSR city & KGP city \\
\hline CVM & 6.27 & 2.02 \\
\hline LC & 12.43 & 4.02 \\
\hline LBW & 11.22 & 3.63 \\
\hline PLEDSC & 25.60 & 8.28 \\
\hline
\end{tabular}

Where, PSC: Passively smoked cigarettes, CVM: Cardiovascular mortality; LC: Lung cancer; LBW: Low birth weight; PLFDSC: Percentage lung function decrement of school-aged children;

Table 4

Comparison of $\mathrm{BC}$ mass concentration and $\mathrm{CO}$ concentration relation with other studies.

\begin{tabular}{|llll|}
\hline Parameters & Correlation & Slope & References \\
\hline BC Vs. CO & 0.74 & $12.5 \times 10^{-3}$ & Rhoads et al., 1997 \\
\hline BC Vs. CO & 0.74 & $15 \times 10^{-3}$ & Chowdhury et al., 2001 \\
\hline BC Vs. CO & 0.74 & $3.4 \times 10^{-3}$ & Chen et al., 2001 \\
\hline BC Vs. CO & 0.71 & $27 \times 10^{-3}$ & Bracero et al., 2002 \\
\hline BC Vs. CO & 0.81 & $15.5 \times 10^{-3}$ & Lobert and Harris 2002 \\
\hline BC Vs. CO & 0.074 & $3.48 \times 10^{-3}$ & Stehar et al., 2002 \\
\hline BC Vs. CO & 0.074 & $6.4 \times 10^{-3}$ & Latha et al., 2004 \\
\hline
\end{tabular}

\section{Conclusion}

Measurements of $\mathrm{BC}$ mass concentrations, $\mathrm{CO}$ concentration and $\mathrm{PM}_{2.5}$ concentrations were reported in two different East India cities, i.e., one is JSR city and the other is KGP city. The averaged BC mass concentrations were reported in JSR city

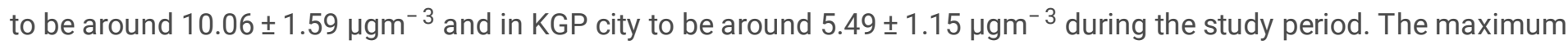

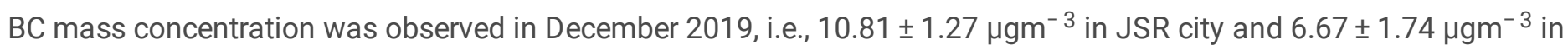

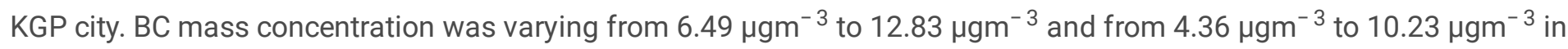
JSR city and KGP city, respectively. Similarly, the averaged CO concentrations were noticed to be around $913.63 \pm 217.85$ ppbv and $507.31 \pm 125.06$ pbbv in JSR city and KGP city, respectively, during the study period. The maximum CO concentration was observed in December 2019, i.e., $958.53 \pm 196.24$ ppbv and minimum in November 2019, i.e., $870.47 \pm$ 172.12 ppbv and CO concentration varied from 416 ppbv to 1402.32 ppbv in JSR city. Similarly, in KGP city, the CO concentration was observed maximum in October 2019, i.e., $542.75 \pm 96.30$ ppbv and minimum in November 2019, i.e., $419.51 \pm 97.63$ ppbv and CO concentration varied from 257.80 ppbv to 840.60 ppbv. The averaged $\mathrm{PM}_{2.5}$ concentrations

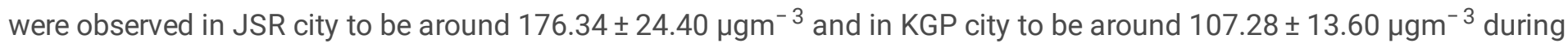
study period. The maximum $\mathrm{PM}_{2.5}$ concentrations were reported in December 2019, i.e., $183.93 \pm 21.63 \mu \mathrm{gm}^{-3}$ and 118.73

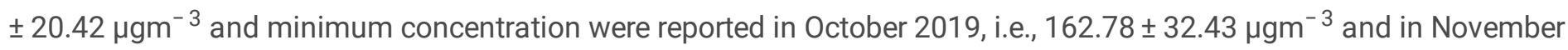
2019 i.e., $101.74 \pm 7.76 \mu \mathrm{gm}^{-3}$ in JSR city and KGP city, respectively, during the study period. And also, $\mathrm{PM}_{2.5}$ 


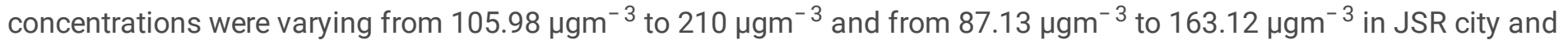
KGP city respectively. According to BC's diagnostic ratio analysis, it was noticed that the fossil fuel contribution was approx. $60 \%$ and wood-burning contribution approx. $40 \%$ in JSR city and the fossil fuel contribution was approx. $57.57 \%$ and wood-burning contribution approx. $42.42 \%$ in KGP city. The wood-burning contribution was higher in KGP city than JSR city during the study period. This is because of more industrialization and high traffic load in JSR city. According to backward air trajectories analysis shows that in the JSR region, the maximum air particulate coming from the northern state, eastern state, and some part Jharkhand. Few particulates come from north-east states and other countries like Pakistan, Nepal, and Bhutan. Similarly, in the KGP region, air particulate matter came from a northern state, eastern, northeast state and some parts of West Bengal and came from some other countries like Bangladesh, Nepal, and Bhutan. The entire health risk assessment of BC concentration was reported as 6.27, 12.43, 11.22 and 25.60 in JSR city and 2.02, 4.02, 3.63 and 8.28 in KGP city, the passive cigarettes comparable concerning the risk of CVM, LC, LBW, and PLEDSC, respectively.

\section{Declarations}

\section{Acknowledgements}

The SERB financially supported the research- DST (Science \& Engineering Research Board, Department of Science \& Technology) Government of India, Sanction Order No ECR/2017/000597. The author thanks the Research supervisor, all lab mates, and institute staff for their helping during this study. The author also thanks NASA Giovani, NASA FIRMS (Fire Information for Resource Management System). The Meteorological Data Explorer was developed by the Centre for Global Environmental Research (CGER), Japan (METEX, http://db.cger.nies.go.jp/metex/trajectory.html) and for the provision of trajectories used in the publication. The daily mean temperature, rainfall, and relative humidity data are used in the study are reported from https://www.worldweatheronline.com.

Availability of data and materials: Not applicable

Author contribution Conceptualisation: BA, TKS, LKS, SG and ASG. Data curation: BA, TKS, and LKS. Formal analysis: BA, TKS, ASG, and SG. Funding acquisition: BA. Investigation: BA, TKS, LKS, SG, and ASG. Methodology: BA, and TKS. Project administration and resource: BA. Software: BA, TKS, and LKS. Supervision and validation: BA, TKS, LKS, ASG and SG.

Visualisation: BA, TKS, LKS, ASG and SG. Writing original draft: BA, LKS, and SG. Writing - review and editing: BA, SG, ASG.

Funding: Open access funding provided by Università degli Studi di Salerno within the CRUI-CARE Agreement. This work was financially supported by Fondi di Ateneo per la Ricerca di Base (FARB 2016 grant no. ORSA 167988) University of Salerno.

\section{Declarations}

Ethics approval and consent to participate: Not applicable

Consent for publication: Not applicable

Competing interests: The authors declare no competing interests

\section{References}

Allen GA, Lawrence J, Koutrakis P. Field validation of a semicontinuous method for aerosol black carbon (aethalometer) and temporal patterns of summertime hourly black carbon measurements in southwestern PA, Atmos. Environ. 1999;33, 817- 823 . 
Akimoto H. Global air quality and pollution. Science 2003; 302: 1716-19.

Bond TC, Zarzycki C, Flanner MG, Koch DM. Quantifying immediate radiative forcing by black carbon and organic matter with the Specific Forcing Pulse, Atmos. Chem. Phys. 2011; 11, 1505-1525.

Babu SS, Moorthy KK. Aerosol black carbon over a tropical coastal station in India. Geophy. Res. Letters. 2002; 29, 13-1113-14.

Belis CA, Karagulian F, Larsen BR, Hopke PK. Critical review and meta-analysis of ambient particulate matter source apportionment using receptor models in Europe. Atmos. Environ. 2013;69, 94-108.

Bond T, Doherty S, Fahey D, Forster P, Berntsen T, DeAngelo B, Flanner M, Ghan S, Kärcher B, Koch D. Bounding the role of black carbon in the climate system: a scientific assessment, J. Geophys. Res.-Atmos. 2013; 118, 5380-5552.

Bracero M, Gabreil R, Andreae MO, Kirchstetter TW, Novakov T, Streets DG. Carbonaceous aerosols over the Indian Ocean during INDOEX: chemical characterization, optical properties and probable sources. J. Geophys. Res. 2002;10, 10291034.

Chen LWA, BG. Doddridge RR, Dickerson JC, Chow PK, Mueller J, Quinn WA, Butler. Seasonal variations in elemental carbon aerosol, carbon monoxide and sulfur dioxide: Implications for sources, Geophys. Res. Lett. 2001; 28,1711 - 1714.

Cooke WF, Liousse C, Cachier H, Feichter J. Construction of a 11 fossil fuel emissions data set for carbonaceous aerosols and implementation and radiative impact in the ECHAM4 model. J. Geophys. Res. 1999;104 (18), 22137-22162.

Dachs J, Eisenreich SJ. Adsorption onto aerosol soot carbon dominates gas-particle partitioning of polycyclic aromatic hydrocarbons. Environ. Sci. Technol. 2000; 34, 3690-3697.

Elsayed NM, Salem H. Chemical warfare agents and nuclear weapons. In Inhalation Toxicology, 2nd edition (H. Salem, S.A. Katz, eds), 2006;521-42. CRC Taylor \& Francis, Boca Raton.

Favez O, Haddad Ell, Piot C, Bor_eave A, Abidi E, Marchand N, Jaffrezo JL, Besombes JL, Personnaz, MB, Sciare J, Wortham H, George C, D’Anna B. Inter-comparison of source apportionment models for the estimation of wood-burning aerosols during wintertime in an Alpine city (Grenoble, France). Atmos. Chem. Phys. 2010;10, 5295-5314.

Fawcett T, Moon R, Fracica P, Mebane G, Theil D, Piantadosi C. Warehouse workers' headache. Carbon monoxide poisoning from propane fueled forklifts. J. Occup. Med. 1992; 34: 12-15.

Florou K, Papanastasiou DK, Pikridas M, Kaltsonoudis C, Louvaris E, Gkatzelis GI, Patoulias D, Mihalopoulos N, Pandis SN. The contribution of wood-burning and other pollution sources to wintertime organic aerosol levels in two Greek cities. Atmos. Chem. Phys. 2017; 17, 3145-3163.

Fuller GW, Tremper AH, Baker TD, Yttri KE, Butterfield D. Contribution of wood burning to PM10 in London. Atmos. Environ. $2014 ; 87,87-94$.

Girach IA, Nair VS, Babu SS, Nair PR. Black carbon and carbon monoxide over Bay of Bengal during W_ICARB: source characteristics, Atmos. Environ. 2014; 94, 508- 517.

Herich H, Hueglin C, Buchmann B. (2011). A 2.5 year's source apportionment study of black carbon from wood burning and fossil fuel combustion at urban and rural sites in Switzerland. Atmos. Measure. Techniq. 2011;4, 1409-1420.

He CL, Li QB, Liou KN, Qi L, Tao S, Schwarz JP. Microphysics-based black carbon aging in a global CTM: constraints from HIPPO observations and implications for global black carbon budget. Atmos. Chem. Phys. 2016; 16, 3077-3098. 
Hoffmann D, Hoffmann I, El-Bayoumy K. The less harmful cigarette: a controversial issue. Chem. Res. Toxicol. 2001; 14: 767-90.

Huang Y,Wu S, Dubey MK, French NH F. Impact of aging mechanism on model simulated carbonaceous aerosols. Atmos. Chem. Phys. 2013;13, 6329-6343.

Janssen NH, Janssen N, Gerlofs NM.. Health Effects of Black Carbon. World Health Organization, Copenhagen, Denmark. 2012

Kelly FJ, Fussell JC. Air pollution and public health: emerging hazards and improved understanding of risk. Environ. Geochem. Health. 2015;37, 631-649

Lanz VA, Alfarra MR, Baltensperger U, Buchmann B, Hueglin C, Szidat S, Wehrli MN, Wacker L, Weimer S, Caseiro A, Puxbaum H, Prevot ASH. Source attribution of submicron organic aerosols during wintertime inversions by advanced factor analysis of aerosol mass spectra, Environ. Sci. Technol.2008; 42, 214-220.

Larsen BR, Gilardoni S, Stenstrom K, Niedzialek J, Jimenez J, Belis CA. Sources for PM air pollution in the Po Plain, Italy: II. Probabilistic uncertainty characterization and sensitivity analysis of secondary and primary sources. Atmos. Environ. 2012;50, 203-213.

Liu Y, Yan C, Zheng M. Source apportionment of black carbon during winter in Beijing. Sci.Tot Environ. 2018; 618, 531-541.

Magalhaes S, Baumgartner J, Weichenthal S. Impacts of exposure to black carbon, elemental carbon, and ultrafine particles from indoor and outdoor sources on blood pressure in adults: a review of epidemiological evidence. Environ. Res. 2018;161, 345-353.

Niranjan R, Thakur AK. The toxicological mechanisms of environmental soot (black carbon) and carbon black: focus on oxidative stress and inflammatory pathways. Front. Immunol. 2017; 8, 763.

Oberdorster G, Sharp Z, Atudorei V, Elder A, Gelein R, Lunts A, Kreyling W, Cox C. Extrapulmonary translocation of ultrafine carbon particles following wholebody inhalation exposure of rats, J. Toxic Env. Health, 2002; 65, 1531.

Oberg M, Jaakkola MS, Prüss-Üstün A, Schweizer C, Woodward A. 2010. Second Hand Smoke, Assessing the Environmental Burden of Disease at National and Local Levels, vol. 18. World Health Organization, Geneva, Environmental Burden of Disease Series. http://www.who.int/quantifying_ehimpacts/ publications/SHS.pdf.

Pani SK, Wang SH, Lin NH, Chantara S, Lee CT, Thepnuan D. Black carbon over an urban atmosphere in northern peninsular Southeast Asia: Characteristics, source apportionment, and associated health risks. Environ. Pollut. 2020;259 113871.

Peters A, Liu E, Verrier RL, Schwartz J, Gold DR, Mittleman M, Baliff J, Oh JA, Allen G, Monahan K, Dockery DW. Air pollution and incidence of cardiac arrhythmia, Epidemiol. 2000;11,11-17.

Prasad P, Raman MR, Ratnam MV, Chen WN, Rao SB, Gogoi MM, Kompalli SK, Kumar KS, Babu SS. Characterization of atmospheric black carbon over a semi-urban site of Southeast India: Local sources and long-range transport. Atmos. Res. $2018 ; 213,411-421$.

Petzold A, Ogren JA, Fiebig M, Laj P, Li SM, Baltensperger U, Holzer-Popp T, Kinne S, Pappalardo G, Sugimoto N,Wehrli C, Wiedensohler A Zhang XY. Recommendations for reporting "black carbon" measurements. Atmos. Chem. Phys. 2013;13, 8365-8379. 
Rothman KJ, Greenland S, Lash TL. Modern Epidemiology. Wolters Kluwer/Lippincott Williams \& Wilkins, Philadelphia, 2008; 53-77.

Rupakheti D, Adhikary B, Praveen PS, Rupakheti M, Kang S, Mahata KS, Naja M, Zhang Q, Panday AK, Lawrence MG. Premonsoon air quality over Lumbini, a world heritage site along the Himalayan foothills. Atmos. Chem. Phys. 2017;17, 11041-11063.

Sahu LK, Tripathi N, Yadav R. Observations of trace gases in the earth's lower atmosphere: instrumentation and platform. Current Sci. 2020;118(12), 1893.

Sciare J, D’Argouges O, Sarda-Esteve R, Gaimoz C, Dolgorouky C, Bonnaire N, Favez O, Bonsang B, Gros V. Large contribution of water-insoluble secondary organic aerosols in the region of Paris (France) during wintertime. J. Geophys. Res. 2011;116, D22203.

Simmonds P, Manning A, Derwent R, Ciais P, Ramonet M, Kazan V, Ryall D. A burning question: Can recent growth rate anomalies in the greenhouse gases be attributed to large scale biomass burning events?, Atmos. Environ. 2005; 39, 25132517.

Srivastava, A.K., Singh, S., Pant, P., Dumka, U.C., Characteristics of black carbon over Delhi and Manora Peak-a comparative study. Atmos. Sci. Lett. 13. http://dx.doi.org/10.1002/asl.386, 2012b; 223-230 (July).

Szidat S, Jenk TM, Signal H.-A, Kalberer M, Wacker L, Hajdas I, Kasper-Giebl A, Baltensperger U. Contributions of fossil fuel, biomass-burning, and biogenic emissions to carbonaceous aerosols in Zurich as traced by 14C, J. Geophys. Res. $2006 ; 111$.

Thepnuan D, Chantara S, Lee CT, Lin NH, Tsai YI, (2019). Molecular markers for biomass burning associated with the characterization of PM2.5 and component sources during dry season haze episodes in Upper South East Asia. Sci. Tot. Environ. 2019;658, 708-722.

van der Werf GR, Randerson JT, Giglio L, Collatz GJ, Kasibhatla PS, Arellano Jr. AF. Interannual variability in global biomass burning emissions from 1997 to 2004, Atmos. Chem. Phys. 2006;6, 3423-3441,

Venkataraman C, Habib G, Kadamba D, Shrivastava M, Leon J-F, Crouzille B, Boucher O, Streets DG. Emissions from open biomass burning in India: Integrating the inventory approach with high resolution Moderate Resolution Imaging Spectroradiometer (MODIS) active-fire and land cover data. Global Biogeochemical Cycles. 2006; 20: GB2013.

Wang QY, Liu SX, Zhou YQ, Cao JJ, Han YM, Ni HY, Zhang NN, Huang R J. Characteristics of black carbon aerosol during the Chinese lunar year and weekdays in Xi'an, China, Atmosphere-Basel. 2015; 6, 195-208.

Wang Y, Hopke PK, Utell MJ. Urban-scale spatial-temporal variability of black carbon and winter residential wood combustion particles. Aerosol Air Qual. Res. 2011; 11, 473-481.

Weingartner E, Saathoff H, Schnaiter M, Streit N, Bitnar B, Baltensperger, U. Absorption of light by soot particles, determination of the absorption coefficient by means of aethalometers. J. Aerosol Sci. 2003;34, 1445-1463.

WHO (World Health Organization)., 2014. Burden of Disease from Air Pollution.

http://www.who.int/phe/health_topics/outdoorair/databases/FINAL_HAP_AAP_BoD_24March2014.pdf, 02.02.16.

WHO (World Health Organization)., (2003). Health Aspects of Air Pollution with Particulate Matter, Ozone and Nitrogen Dioxide. http://www.euro.who.int/ document/e79097.

Page 13/19 
Zhang YL, Huang RJ, El Haddad I, Ho KF, Cao JJ, Han Y, Zotter P, Bozzetti C, Daellenbach KR, Canonaco F, Slowik JG, Salazar G, Schwikowski M, Schnelle-Kreis J, Abbaszade G, Zimmermann R, Baltensperger U, Prevot ASH, Szidat S. Fossil vs. non-fossil sources of fine carbonaceous aerosols in four Chinese cities during the extreme winter haze episode of 2013. Atmos. Chem. Phys. 2015;15, 1299-1312.

Zotter P, Herich H, Gysel M, El-Haddad I, Zhang Y, Mo_cnik G, Hüglin C, Baltensperger U, Szidat S, Pr_ev^ot ASH. Evaluation of the absorption Ångstr€om exponents for traffic and wood burning in the Aethalometer-based source apportionment using radiocarbon measurements of ambient aerosol. Atmos. Chem. Phys. 2017; 17, 4229-4249.

\section{Figures}

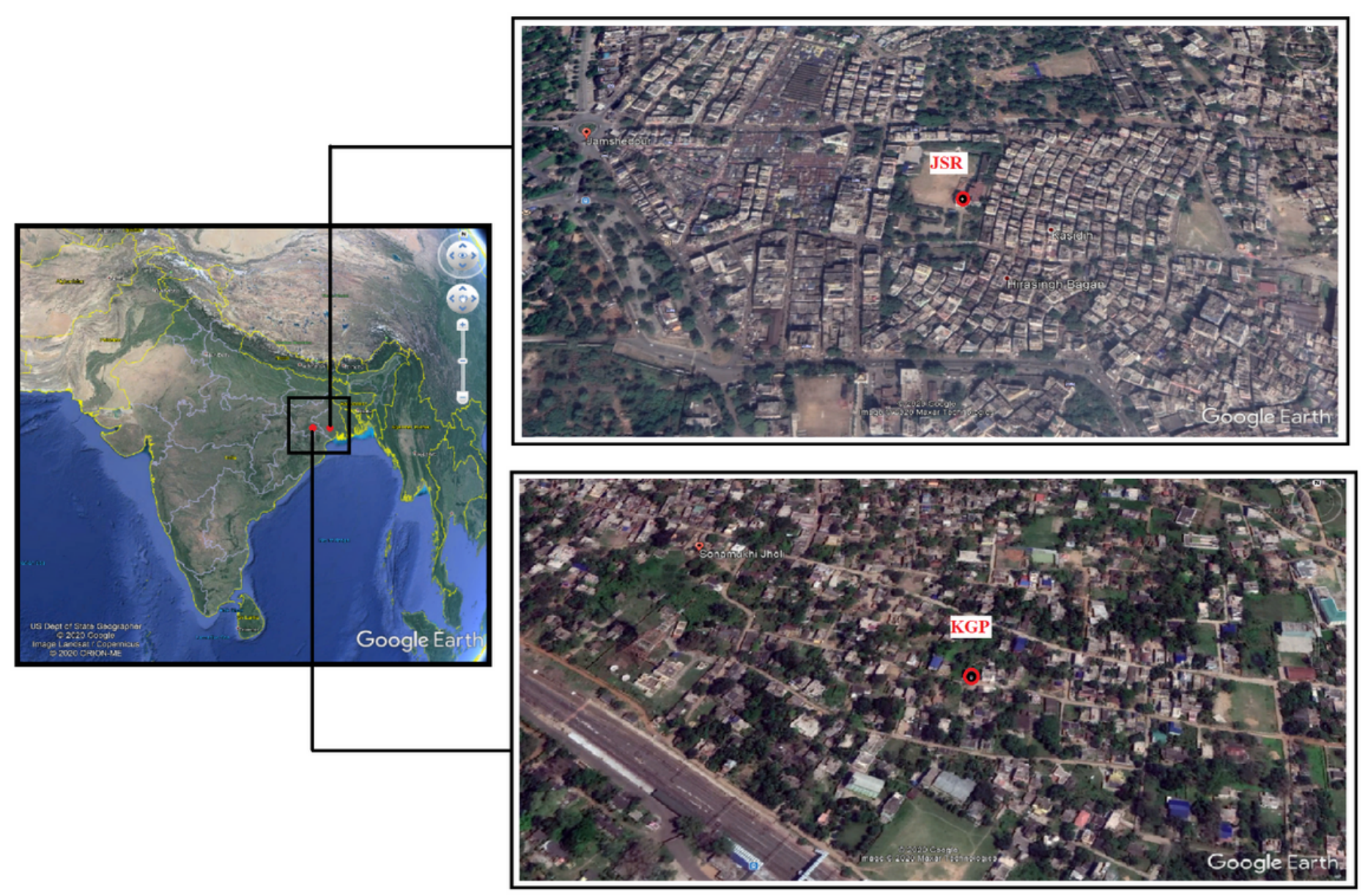

\section{Figure 1}

Satellite aerial view (Google Earth) of the sampling area and location of two different cities of Jamshedpur (JSR) and Kharagpur (KGP) in the eastern part of India. Note: The designations employed and the presentation of the material on this map do not imply the expression of any opinion whatsoever on the part of Research Square concerning the legal status of any country, territory, city or area or of its authorities, or concerning the delimitation of its frontiers or boundaries. This map has been provided by the authors. 


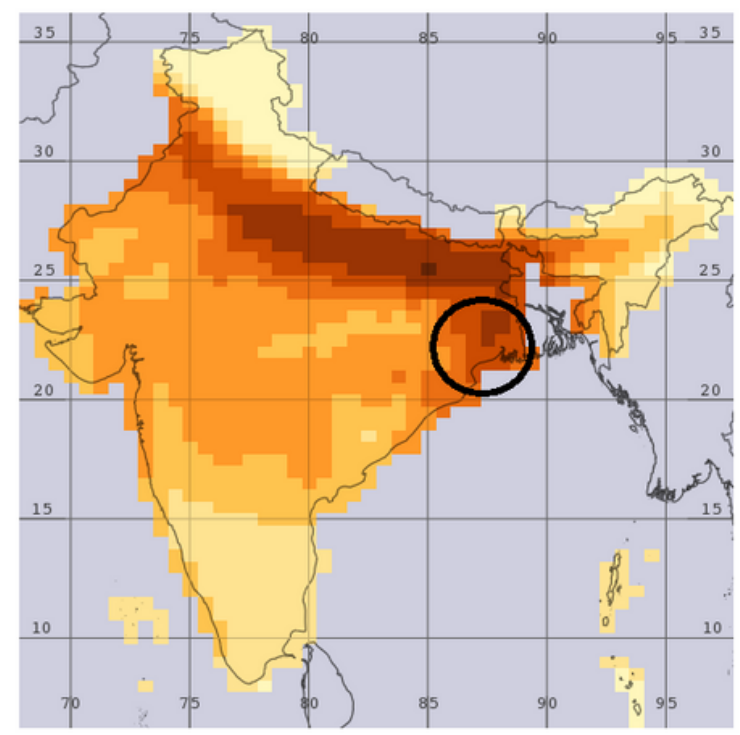

(a)

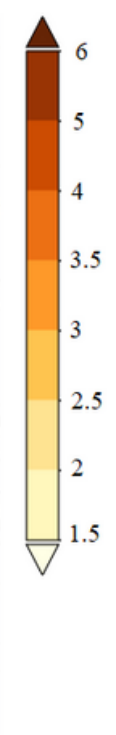

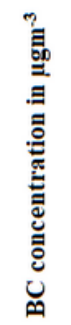

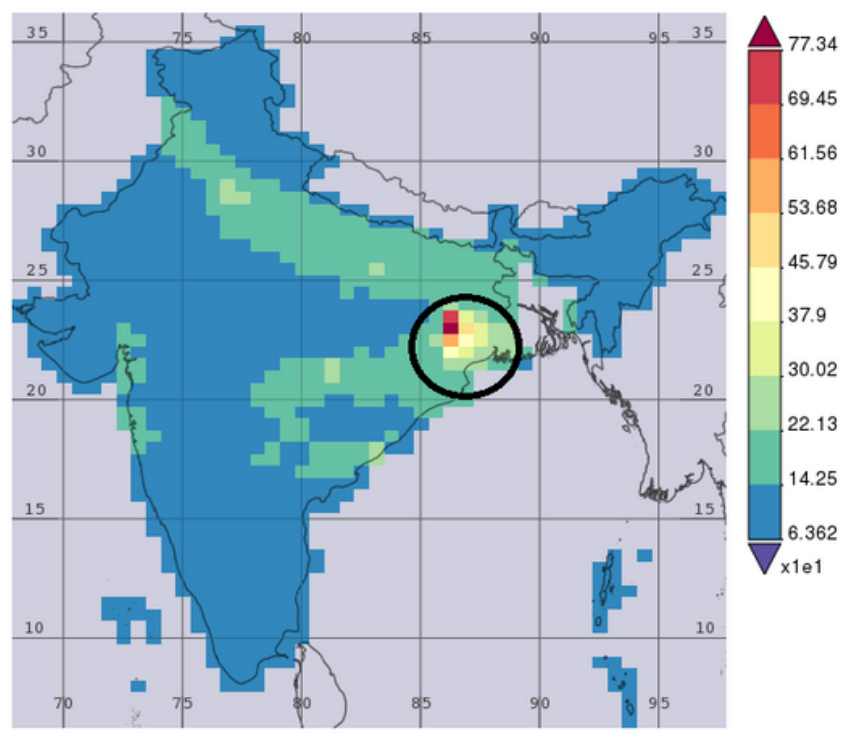

(b)

\section{Figure 2}

(a) Time average map of Black carbon surface mass concentration monthly $0.5 \times 0.625$ deg. [MERRA-2 Model M2TMNXAER v 5.12.4] $\mu \mathrm{gm}-3$ and (b) Time average map of CO concentration in pbbv (ENSEMBLE) monthly $0.5 \times 0.625$ deg. [MERRA-2 Model M2TMNXCHM v 5.12.4] ppbv, over Oct-2019 to Jan-2020, India. Note: The designations employed and the presentation of the material on this map do not imply the expression of any opinion whatsoever on the part of Research Square concerning the legal status of any country, territory, city or area or of its authorities, or concerning the delimitation of its frontiers or boundaries. This map has been provided by the authors. 


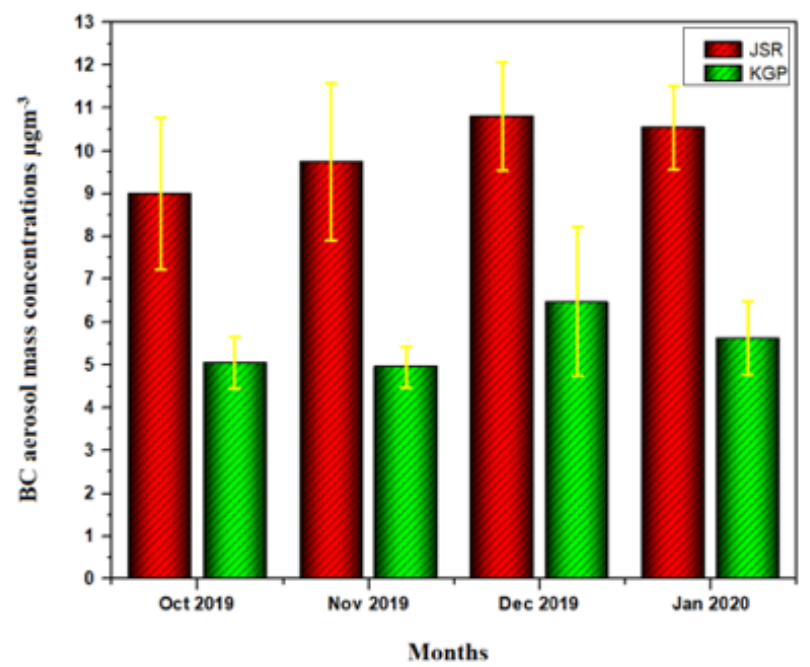

(a)

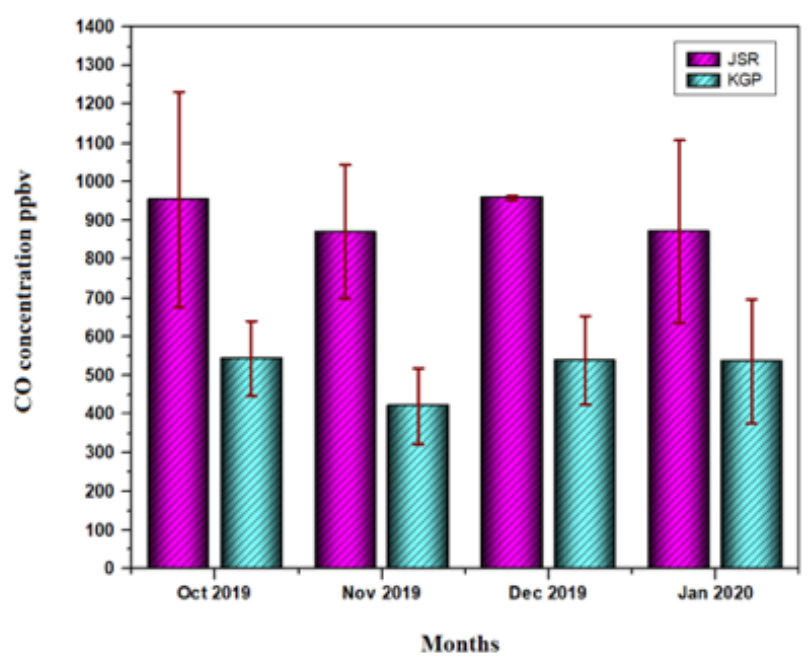

(b)

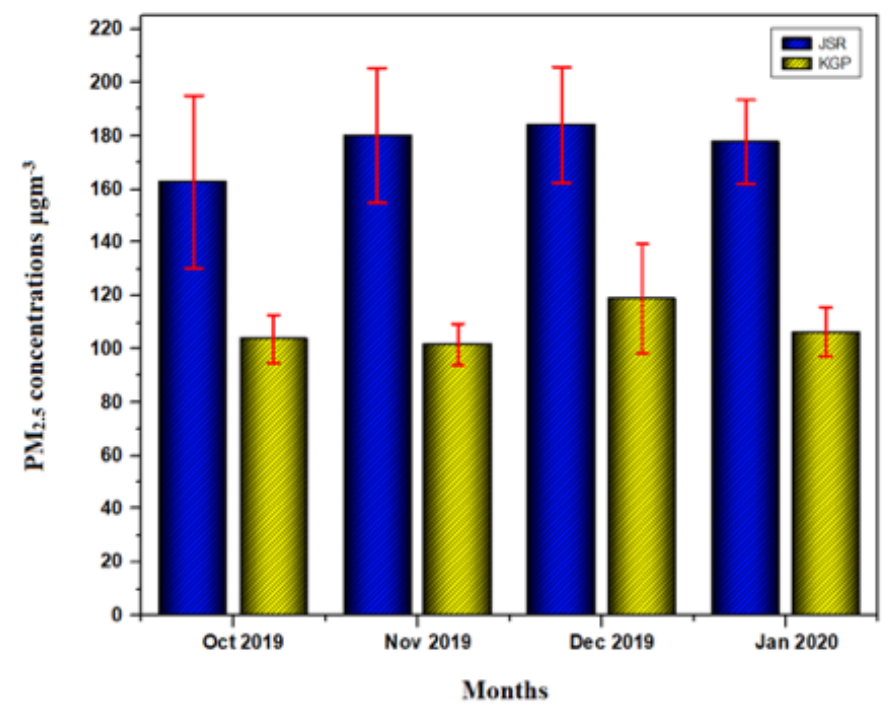

(c)

Figure 3

Average concentrations of (a) BC mass concentration; (b) CO concentration; and (c) PM2.5 concentration at two different cities of Jamshedpur (JSR) and Kharagpur (KGP) in the eastern part of India. The vertical line represents 1-sigma variation (standard deviation). 


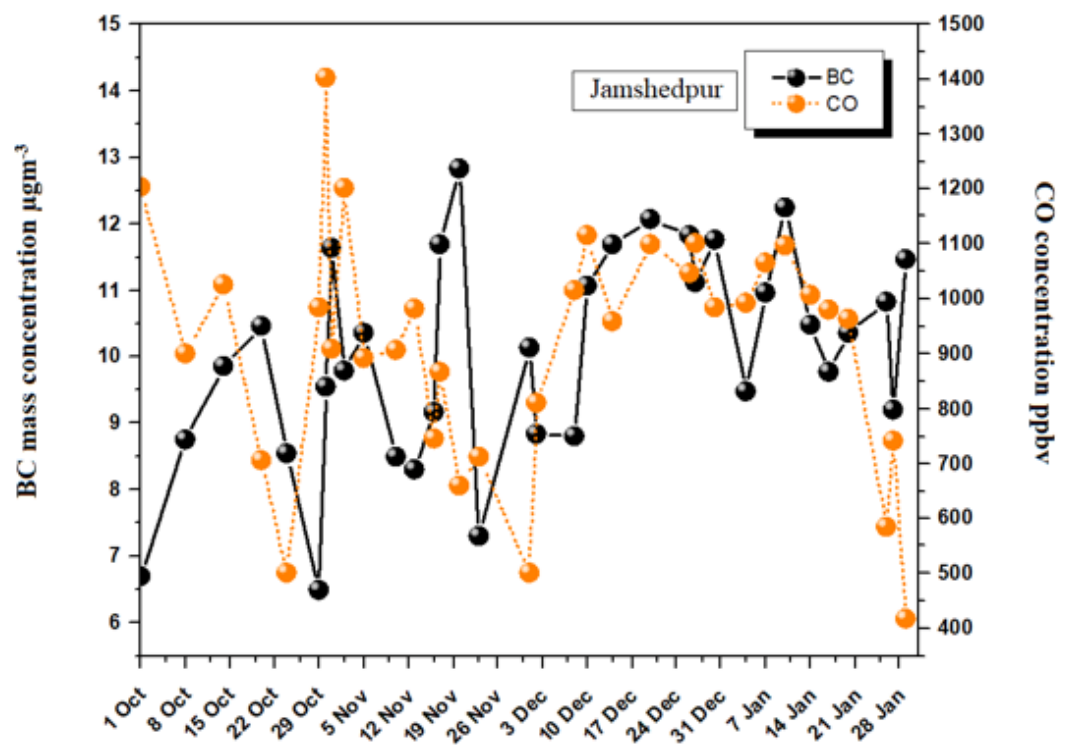

(a)

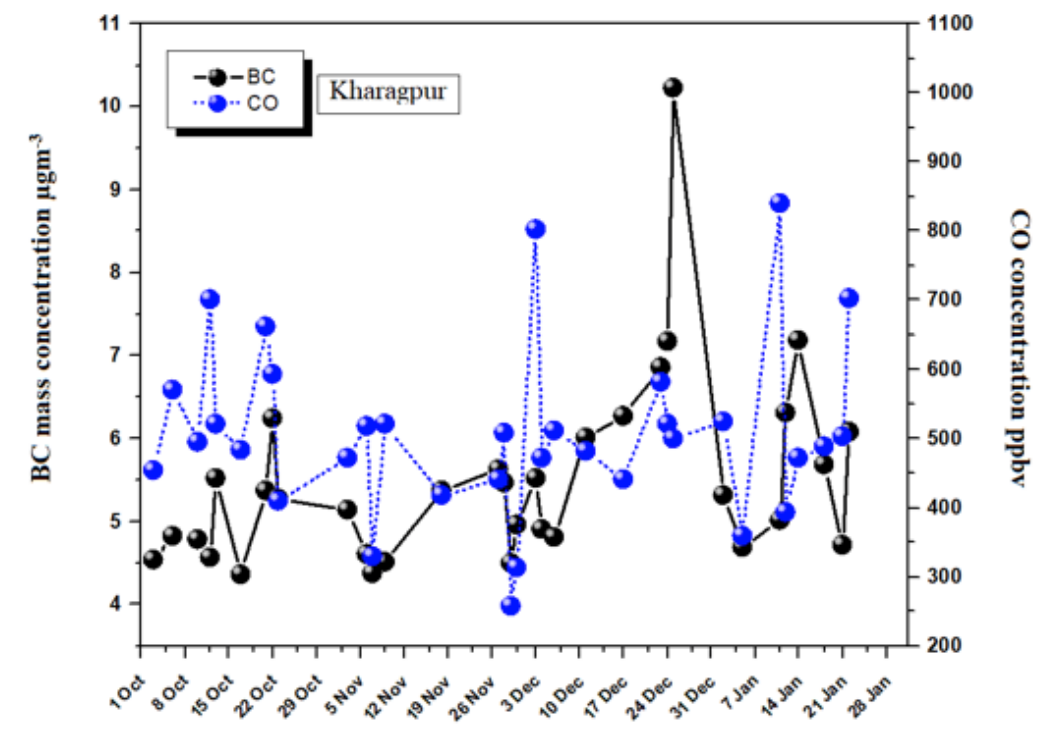

(b)

Figure 4

Daily variation of BC and CO concentration at two different cities (a) JSR city, and (b) KGP city of East India during study period. 

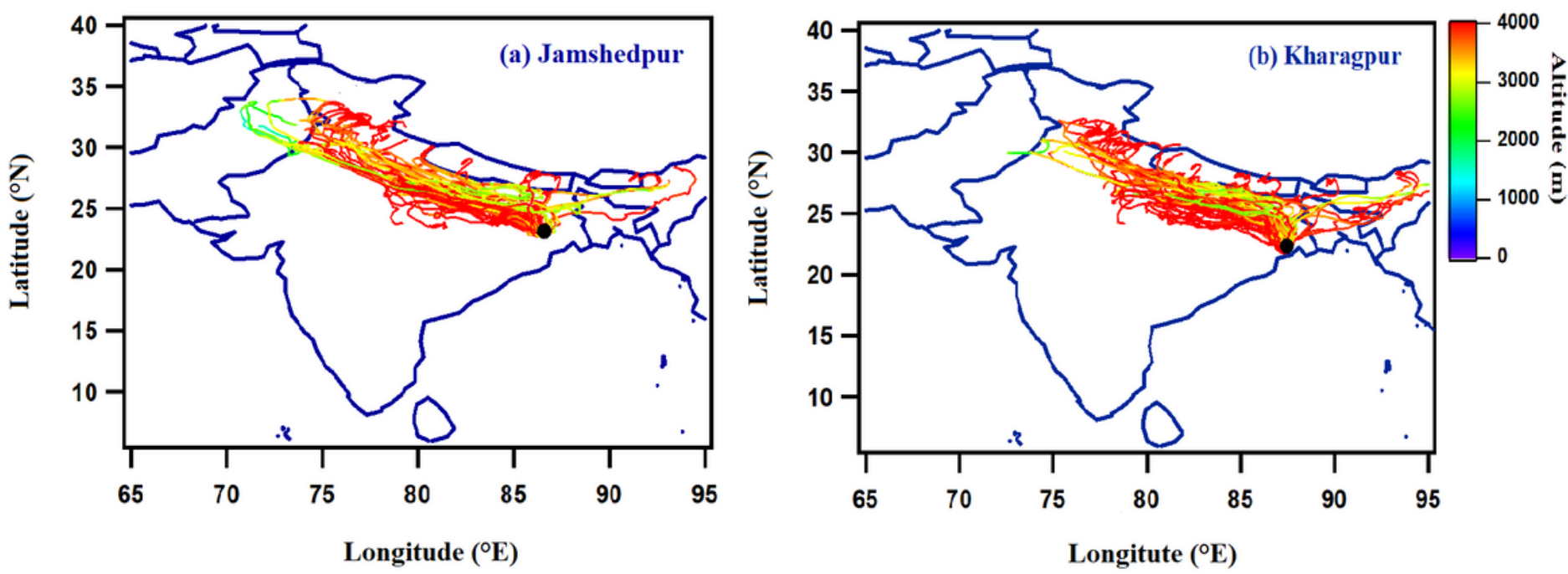

Figure 5

7-days air mass back-trajectories at two different cities of East India (a) JSR city (b) KGP city, at altitude level of 500m above ground level, over sampling side. Note: The designations employed and the presentation of the material on this map do not imply the expression of any opinion whatsoever on the part of Research Square concerning the legal status of any country, territory, city or area or of its authorities, or concerning the delimitation of its frontiers or boundaries. This map has been provided by the authors.

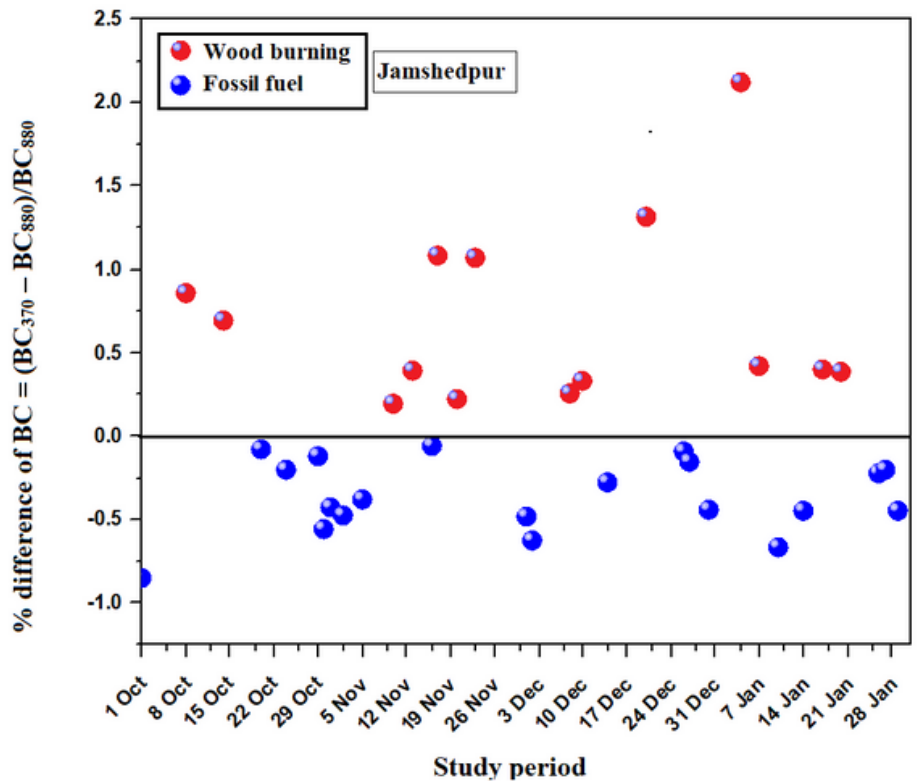

(a)

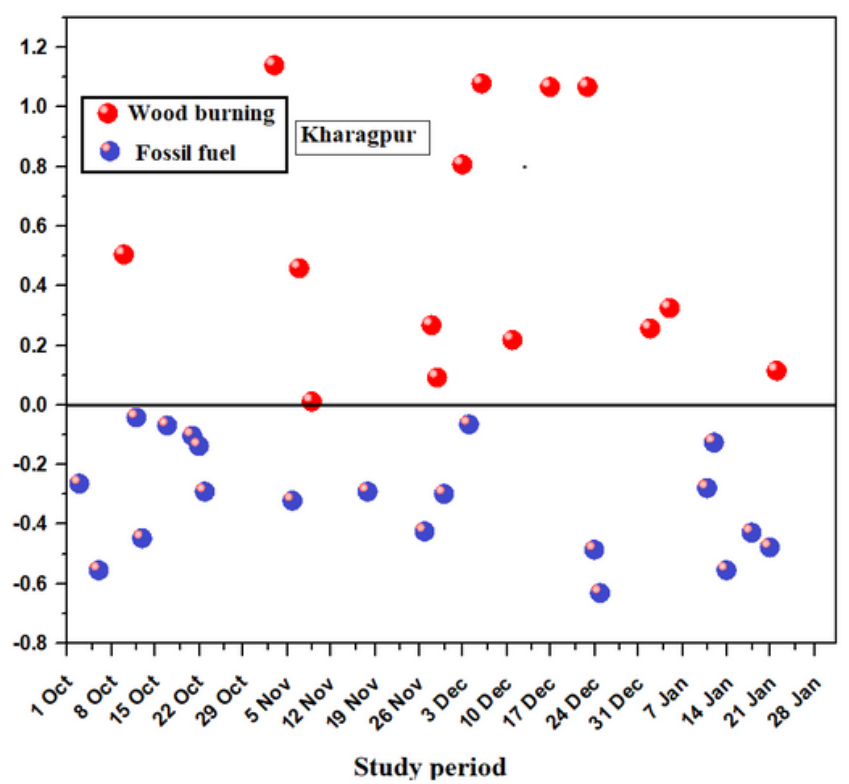

(b)

\section{Figure 6}

Fractional contribution of BC measured at BC370 (370 nm) and BC880 (880 nm) at two different cities (a) JSR city, and (b) KGP city of East India. 

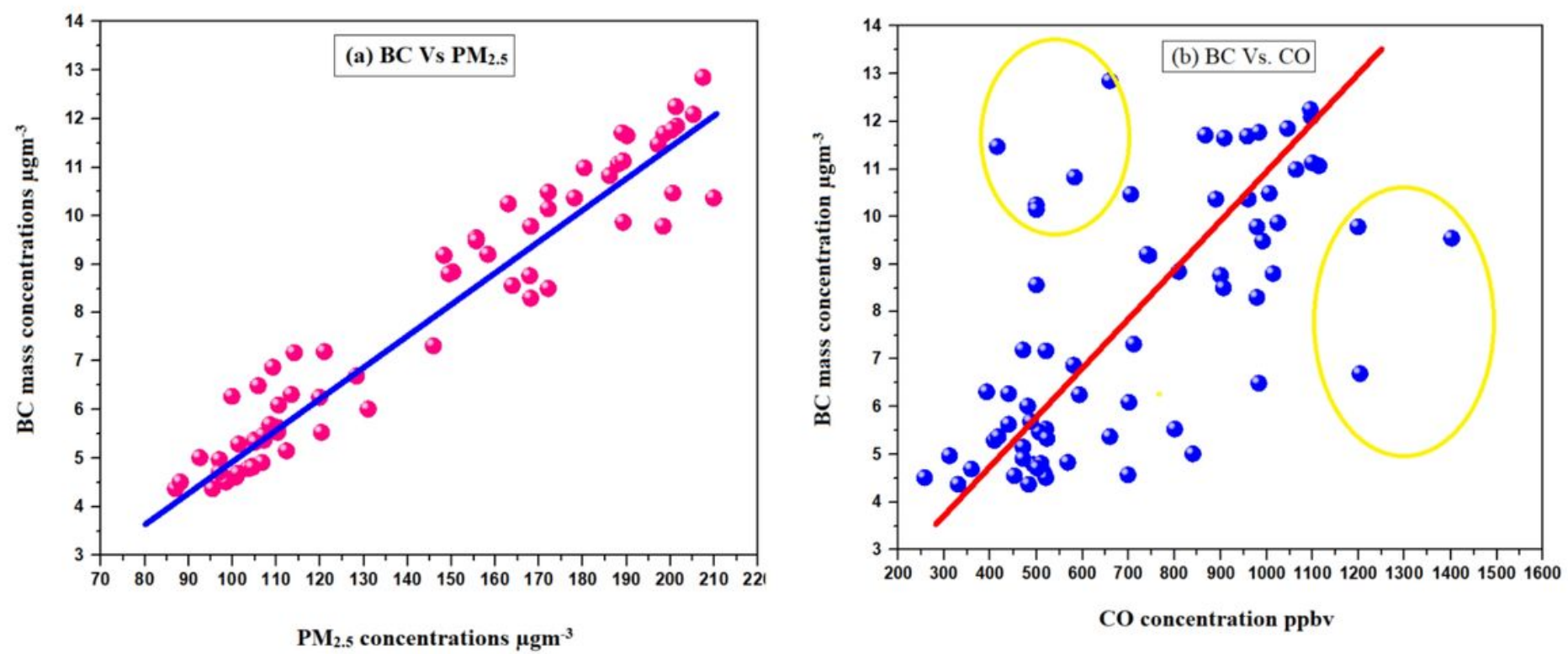

Figure 7

Scatterplot of (a) the BC-PM2.5 correlations and (b) the BC-CO correlation during study period at two different cities of East India. 